\title{
Strategy Study on Primary School English Game Teaching
}

\author{
Feng $\mathrm{He}$ \\ Primary Education College, Linyi University Linyi, Shandong, China \\ wangyinuo_2007@163.com
}

Keywords: Strategy; Study; Primary school; English game teaching

\begin{abstract}
English games teaching in Primary School integrates teacher's morals, education notions and teaching skills into students' activities. In game teaching, students and teachers are dual subjects in the process of interaction and mutual promotion. In preparing lessons, teachers should consider students' condition, teaching contents, learning goals, important and difficult points, teaching surroundings and all other factors concerning the formulation and implementation of teaching strategies. In classroom teaching, teachers should be guided by systematical teaching strategies to achieve the purpose of generation in presumption and presumption in generation, grasping teaching opportunities, selecting proper methods, applying effective means, creating appropriate situations, evaluating teaching activities timely and gaining the best teaching effects to play the full role of English game teaching strategy in Primary school.
\end{abstract}

\section{Introduction}

Game teaching method reflects the main body status of students in English learning because it emphasizes the role of emotional factors and activities in teaching. Psychologists believe that "the lack of direct interest can make learning become dull burden; on the other hand, the fact that students are interested in learning contents can produce a strong thirst for knowledge and their learning enthusiasm will obviously increase.” Beijing Normal University professor Wang Qiang said: "whether students gain success in learning English, to a large extent, depends on their interest in learning. Therefore, the primary school English teaching should pay attention to stimulate students' strong desire to learn English, make them willing to learn; and the keep of interest in learning, to a great extent, depends on the learning effect and whether they can get a sense of achievement." She also thinks that the overall target of the primary school English teaching should emphasize on interest, sense of accomplishment and self-confidence." Small but varieties of games are "catalyst" of further improving the learning interest."

\section{The Concept of Game Teaching and Game Teaching Method}

Game teaching is the combination of education and games. There are two kinds: one is computer games with education significance, namely, the goal of the game does not serve for teaching, but can be used for teaching because of its incentive mechanism, game process, game environment, game rules, motive component and other factors that can achieve teaching goals through the guidance of teachers; the other is subject game especially designed for the teaching goal, which emphasizes teaching with clear teaching targets, specific teaching content and teaching strategy after careful consideration."

Game teaching method is a new way of teaching, which is based on certain game teaching theory, aiming to strengthen text teaching, master new words, exercise students' language practice ability, develop their potential and intelligence and organize English activities step by step according to certain procedures. Game teaching method tries to transform the dull language teaching to a vivid and interesting game easily accepted by students and makes students learn by playing. 
Game teaching method tries to transform the dull language teaching to vivid and interesting games easily accepted by students, which will increase their attention in class and naturally acquire English knowledge and skills in a lively, relaxed and happy atmosphere. This method makes students play by learning and learn by playing through the creation of rich language communicative situation.

\section{The Basic Characteristics of Primary School English Game Teaching}

"Game" in English game teaching doesn't mean humor or funny things in a low level and entertainments without purpose. The English game teaching should first be a kind of education idea, that is, we should not be limited to the game itself but inspect its connotation from the perspective of happy teaching, interest teaching and successful teaching; next, in the English class, the game should become a unique style of teaching art and a method and way of studying English.

Emotionality. As English teachers, we should make students clear the true meaning of English study. In terms of primary school students, the fact that their minds are not yet mature results in their not fully understanding the real meaning of learning English experience, so teachers need to give them continuous guidance and infiltration. In the process of game, children virtually experience the joy of learning English, gradually clear the necessity of learning English and natural accept English culture from emotion.

Knowledge. English learning is a process of students' constant acquisition. In the English game teaching, teachers must ensure rich knowledge content in specific time, including the comprehensive practice of listening, speaking, reading, writing and using, such as the accumulation of vocabulary, sentence structure, discourse reading, pronunciation skills, the cultivation of language sense, oral communication and writing and so on. Game is just one of the carriers of the knowledge and skills training. Rich and colorful games make students integrate into the specific context, its role of communication; instrument and humanism also gradually get played.

Humanism. In the process of English game teaching, teachers should guide students to learn to respect, learn to listen, learn to express, learn to collaborate, and learn to appreciate... Its learning is interlinked with other disciplines and plays a very important role in children's healthy growth, which requires English teachers own rich English cultural background information, such as abundant vocabulary accumulation, fluent and Standard English expression, deep love for English and English teaching and sense of responsibility for students and the teaching cause.

Transfer. The connotation of the primary school English game teaching method can be transferred to the teaching of other subjects, and other disciplines of education teaching methods, learning skills can dissolve in the teaching of the English game as well.

Development. Primary school English game teaching inspires students' enthusiasm for learning English, improves the students' skills by themselves and cultivates their "the view of English learning" -- learning English is not only for the individual development, but has its important national significance. This kind of skill and emotion transfers to students' life unconsciously and lays a certain foundation for students' lifelong learning.

Integration. In primary school English game teaching, students' language intelligence, music intelligence, mathematical and logic intelligence, visual spatial intelligence, body movement, natural intelligence, intrapersonal intelligence, interpersonal intelligence and so on will play full roles in English classroom, especially the part of the game and obtain exercise and improvement by watching, listening, speaking, writing, doing, painting, playing, talking, thinking and other forms, which makes students' attainment in other subjects fields or life improved other than English literacy in English class. 


\section{Types of Primary School English Game Teaching}

English game teaching usually has the following several challenge forms: the competition of speed, reaction, memorization, observation, imagination, thinking, etc. There are also other types, such as listening, speaking, reading and writing as well as the combinations of these. Such as: competitive listening game teaching, diagnostic vocabulary game teaching, exploring pronunciation game teaching and practice grammar teaching. Because students would be bored of even if the most interesting game, so game teaching should be diversified and constant innovation in order to keep students enthusiasm for teaching. Specific types are as follows:

The Riddles Games. Riddle is one of the favorite games in the game teaching activities, which integrate the guessing game into the classroom. It is indeed a very good activity form that students feel interested in. It can not only increase students' English knowledge and train their listening and speaking skills, but also develop their intelligence and develop their thinking ability. Some English riddles we can refer to are the followings.

Calculation Riddle. It is designed mainly to examine student oral and mental ability of rapid response, which is an effective method to cultivate students' thinking ability.

Example: Tony is three times as old as Linda, but he is two years younger than Black, what's Linda's age if Black will be twenty years old in three years' time?

Note that when the riddles are given, teachers should say it in English. Students must also answer in English in order to develop their ability of English listening and speaking.

Vocabulary Game. Word competition and making new words. Teachers prepare 78 cards, and each writes a letter. The total of 26 letters writes three times, and then put them into the collection box. Let students take out several cards, of course, cards taken out may be three same letters. Students are required to use as many letters as possible to combine new words.

Investigative Task Game. Let students use English to perform the investigative tasks, which not only can exercise students' English application ability, but also cultivate students' ability of analyzing and solving problems. In view of the limited contents primary students have learned, we can design simple investigative tasks which are easy to perform.

Role Play Game. Teachers make students understand the meanings of the sentence and how to use it through expressions, gestures, physical objects, situation, etc, so that students are able to directly link the language and the situation it expresses, blurt out English and perform it in English. In a special environment, role play will make it easier for students to understand words and sentences.

\section{Steps of Primary school English Game Teaching}

Design Purpose. Language knowledge and subjects are relatively broad in the game activities. We can choose to design the corresponding game when we discuss or use the language knowledge to complete an activity. Usually the design of the game activities is opened around specific language knowledge, such as words and sentences. We transform the previous simple boring repetitive practice into various interesting games through the design of all kinds of game activities, which makes it easier for students to master and consolidate the knowledge.

Carry out the Game. After students understand the rules of the game, the game begins. Teacher plays the role of a guider, organizer, and a referee in a competitive game. Students play the roles of the dominant players and implementers in the process of game. For example, when the teacher gives a word lesson, he must practice to consolidate students' learning through games after learning the new words and then let students master the new knowledge more effectively without feeling bored. In the teaching process teachers use "sharp eyes", "What's missing?", "guessing games" to test the classroom efficiency and whether students have mastered these new words. 
Discuss. Students are divided into groups and complete the task in internal cooperation, in which they would help each other, discuss, and positively think to solve problem. The teacher plays the role of an observer and the helper in the process.

Express and Present. This link is the representation of the final results of the process. Students will present the results of the task in front of the teacher and other groups through the creation of situation and discussion.

Reward Evaluation. Activities in this period are organized and conducted by teachers and students step by step. In this process, the teacher should make timely awards and evaluation. Such as in a competitive game, the teacher can design scoring ways to encourage the enthusiasm of the students. This part is a summary and evaluation to the tasks. After student rendering task achievement in groups, others can evaluate. And the teacher plays a crucial role at this time to make a final evaluation and summary, raising the well-done and correcting deficiencies.

\section{Significance of Primary School English Game Teaching Method}

Stimulate Students' Learning Interest Effectively. Game teaching method makes full use of elementary students' strong curiosity and competitive psychology and the irritation of competition game to promote students' interest in learning English. In particular, education should focus on cultivating students' learning attitude to daring to speak and actively participating in. In this stage the key is to let students experience the pleasure of learning English.

Promote the Development of Students' Multiple Intelligences. Gardner believes that our intelligence is multiple; everyone more or less have different nine kinds of multiple intelligences; the nine kinds of intelligence represent different potential of each person; and the potential can be fully developed only in the appropriate context. Multiple intelligence theory requires that we teachers should know every student's background information, interests and learning strengths to determine the most beneficial education ways suitable for students. In the teaching design, teachers should not only attach great importance to the students' intelligence in different aspects, but also expand the space for the development of intelligence and try to discover each student's potential ability. Although the adoption of English game teaching develops students' ability of speech-language from the view of surface, it makes students multiple intelligences get developed because teachers adopt different game activities.

Promote the Development of Students' Moral Quality. All kinds of noble morality almost can be derived from the game. Autonomy, restraint, honesty, independence, cooperation and obedience all these virtues' formation develops no more quickly than in the games. As for fairness, integrity, respect for the rights of others, personal obligation all these behaviors are the affiliate products of games. Children's mastering of the social moral behavior in the game rules benefits to their awareness and mastering of the social moral behavior in real life.

Develop Students' Intelligence and Improve their Learning Ability. English game teaching can develop students' ability of observation, memory, imagination, thinking and other intelligence factors. Through certain game activities, the students' intelligence can be directly transferred into the ability of learning. Games are generally contains intellectual ingredients, such as through thinking of observation and analysis, speculation, imagination, etc. Students can consolidate the language knowledge, improve skills and be able to develop their capabilities in the process of playing, talking and singing.

Improve the Teaching Efficiency and Achieve Real Effective Teaching. Concept of effective teaching as a teaching theory was put forward just recently. Actually we prefer to use "effective teaching" in a broader sense: all teaching methods that can promote students' development and effectively achieve the desired results of teaching activities can be called "effective teaching". In primary school English game teaching, games should be carefully designed before class and the game content created should be unknown to students. Teachers will help students practice related language knowledge used in the games and carry out games, which will make students use learned language in 
lively way. Students practice continuously and make flexible use of language in the game, which natural result in easy output of language and realizing the acquisition of language. This can effectively improve classroom teaching efficiency and realize effective teaching.

Promote Teachers' Self-development. Primary school English game teaching needs more interaction between teachers and students, and the teachers serve as the developers, guiders and participants of game activities in the interaction between teachers and students, students and students. They give up one-man show acted in the traditional teaching and concern more about students and their guidance to study becomes more comprehensive and specific; teachers will pay more attention to the improvement of classroom management skills and teaching monitoring capability. In this way can teachers maximize their self-development and achieve the ideal state of modern education.

\section{Summary}

In summary, the appropriate use of the game teaching can adjust the classroom atmosphere, attract students' active participation in language practice activities, strengthen students' ability of listening and speaking, make the English teaching become vivid and rich and make the class interesting and lively so as to achieve a satisfactory teaching effect. Adopting vivid and interesting game form, and at the same time paying attention to the organic integration with the teaching goal, you can change the boring language phenomenon into rich language communicative situation, so that students can play by learning and learn by playing, which can lay a good foundation for their further study English in the future.

\section{References}

[1] Liu Dong. Thought about Game-learning. Modern Education[J]. 2004(5) :39-42

[2] Liu Jingguang. Si Zhiguo. Innovation and implement - the carrying-out of adaptive study using game teaching $[\mathrm{J}]$. Primary and Middle School Information Technology Education. 2006(11):12-13.

[3] Cao Zhongping. Theory of children's game[M]. Ningxia people's House, 2000.

[4] Gong Yafu .TPR children English[M]. Foreign Language Teaching and Research Press. 1994.

[5] Guo Yuanxiang. Basic education outline of life and education returning to the world[M]. Central China Normal University Press. 2002.

[6] Hu Chundong. English teaching methodology[M]. Higher Education Press. 1990

[7] Jia Guanjie. Foreign language teaching psychology[M]. Guangxi Education Press, 1990.

[8] Wang Dianjian. Lai Hongling. Primary School English teaching methodology[M]. Beijing University Press. 2002.

[9] Wang Qiang. Primary school English teaching methodology[M] . Higher Education Press. 2003.

[10]Brown H Douglas Teaching by Principles: An Interactive Approach to Language Pedagogy[M]. Beijing: Foreign language Teaching and Research Press. 2001

[11]Brown H Douglas. Understanding Research in Second Language Learning[M]. Beijing: Foreign language Teaching and Research Press. 2001

[12]Byrne Learner-based teaching[M], Oxford Press. 1995

[13]Hadfield, Jill. Elementary Communication Games[M]. London: Nelson. 1984

[14]Hadfield, Jill. Classroom Dynamics[M]. Oxford: OUP. 1998 
[15]Qian Xiaoxia Experimental research report on primary and secondary school English teaching of cultivating learning interest being key. Primary and Secondary School English Teaching and Research. 2002; 3

[16]Gui Shichun. Applied linguistics[M]. Hunan Education Press. 1987

[17] Song Linyi. Five steps of English classroom teaching[M]. China Education and Development. 2005.2 